\title{
EARTHQUAKE HAZARD MAP OF THE HENRYS LAKE QUADRANGLE, IDAHO AND MONTANA \\ By
}

Irving J. Witkind

FOLIO OF THE

HENRYS LAKE QUADRANGLE, IDAHO-MONTANA

MAP 1-781-E

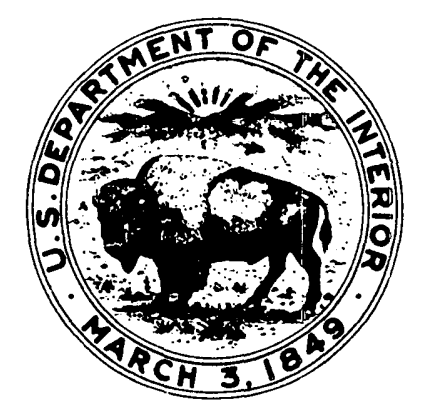

